\title{
A történelmi interpretáció fogalmának tanítása
}

A történelemtanitás és -tanulás eredményessége nagyrészt azon múlik, hogy a diákok képesek lesznek-e a múlt, a történelem és a történelmi interpretáció fogalmát helyesen értelmezni, helyes kép alakul-e ki bennük a múltban történtek és az azokról készült interpretációk viszonyáról. Ennek fontos feltétele, hogy a történelemtanárok maguk is megértsék e probléma összetettségét, és képesek legyenek reflektív módon is megközeliteni a történelemórákon bemutatott ismereteket, következtetéseket és értékeléseket.

\section{A történeti interpretációk célja, típusai és jellegzetességei}

A z emberi csoportok és közösségek létrejönnek és folyamatosan léteznek, részben azoknak a történeteknek köszönhetően, amelyeket maguknak mondanak el arról, hogy kik ők, hol kezdődött a történetük, és hová tartanak, valamint más emlékezésmódok, mint például az évfordulók, emlékezések és emlékmüvek által, amelyek ezeket a narratívákat a rituálék segítségével beágyazzák a társadalom életébe (Lowenthal, 1985; Samuel, 1994). Ezeknek a narratíváknak és emlékezésmódoknak célja az idő múlásának kezelése, az identitás megkonstruálása és stabilizálása, valamint a múlt által a jelen és a jövő számára teremtett korlátok és lehetőségek megértése (Rüsen, 2005). A múlt interpretációnak sokfélesége ezért összefügg a társadalmak etnikai, vallási, kulturális sokszínüségével is, mivel minden közösség és csoport igyekszik megalkotni a maga történelmét.

A múlt mindaz, ami korábban volt és megtörtént, a történelem pedig az, amit és ahogy a fennmaradt források segítségével a későbbi korok emberei mindebből képesek rekonstruálni és bemutatni. A múltat nem lehet teljes valóságában újjáéleszteni és megidézni, és a múltról készült interpretációk helyességét sem lehetséges ily módon ellenőrizni.

A történelmi múlt csak a jelenben létezik a múltból fennmaradt nyomok (írásos és tárgyi emlékek) és a múltról készült interpretációk formájában. Azt tudjuk elmondani a múltról, ami a fennmaradt források és a jelen kérdései és céljai közötti folyamatos párbeszéd eredménye, és ezt számos tényező befolyásolja: pl. a múltra való orientációnk, vagyis hogy mit és miért is tartunk fontosnak belőle, illetve hogy mit is értünk történelmen; a múlt megismerésével kapcsolatos céljaink, kérdéseink, valamint a források kiválasztása, vizsgálata és értelmezése során alkalmazott módszereink (Chapman, 2011).

A történelmi interpretáció konstrukció, amelyet egy adott pillanatban alkot meg egy adott szerző, akinek megvannak a maga szempontjai és céljai azzal, ahogy a múlt forrásaira támaszkodva valamilyen értelmet és jelentést akar adni a múltban lezajlott 
eseményeknek és változásoknak (Chapman, 2016; Rüsen, 2005).

A múlt cseppfolyós, a történeti interpretációk pedig eltérőek és változatosak: maguk is részei a történelemnek, megvan a maguk története, és folyamatosan változnak, ahogy a jelen is változik. Sokan, sokféle módon és sokféle céllal beszélnek és nyilvánítanak véleményt a múltban történtekröl különböző kontextusban, különböző formában és különböző célközönségnek. A sokféle céllal és szempontból elkészült interpretációk sokszor kiegészítik egymást, de sokszor ellent is mondanak egymásnak.

A mód, ahogy a múlt interpretációjának célját kijelöljük és az ehhez a feladathoz rendelkezésre álló forrásokat kiválasztjuk, tükrözi azt, hogy kik vagyunk, és milyen az a hely és az idő, amelyben élünk. A múlt feltárását mindig sajátos célok vagy kérdések vezetik, és bizonyos emberek vagy embercsoportok sajátos meggyőződésekkel és feltételezésekkel fognak bele, és még akkor is, ha a „tény” egyértelmúen megállapítható, az interpretációban kapott jelentésük vitatható lehet (Koselleck, 2004; Samuel, 1994). A múltbeli cselekedeteket óhatatlanul a jelen szemüvegén keresztül nézzük, ezért abban, ahogy a múltban történteket elképzeljük, megjelennek az általunk fontosnak tartott értékek, valamint az is, ahogy mi a világot és a múltban történteket látjuk. Ezért mindig a jelen viszonyai határozzák meg a múltra vonatkozó kérdéseinket, így aztán egy interpretáció egyszerre szól explicit módon a feldolgozott történelmi témáról és implicit módon a saját koráról. Az emlékezet szorosan összefonódik a jövőre vonatkozó A múlt feltárása és az eredmények felhasználása például a jelen megértéséhez összetett és bonyolult. A,történelem több annál, mint amit abból mai világunk értelmezésekor hasznositani tudunk, és jelenünk is több annál, mint amit abból történeti elemzéssel megérthetünk. Másrészt a történelmi magyarázat soha nem abszolút érvényú." (Knausz, 2015. 22.) Annak, hogy a múltban történteknek miként próbálunk értel-

met adni történelemként, számos módja és formája van.

Az interpretációk tartalmát mindig többféle tényezó együttesen határozza meg: a kontextus, amelyekben megszületettek; az a mód, ahogy a történelem fogalmát értelmezik; az általuk alkalmazott értelmezési keret és azok a müfajok és kifejezési formák, amelyekben megfogalmazásra kerültek. Fontos szerepet játszik a múlt különbözó megközelitésmódja is. célokkal és várakozásokkal is. A történelmi interpretáció alakítja a jelenről alkotott képünket, és különböző jövőben megvalósítandó cselekvésekre ösztönöz (Lee, 2004).

A most készülö történelmi interpretációk is egyszer majd elsődleges forrásokká fognak válni a mi korunk gondolkodásmódját vizsgáló jövőbeni kutató számára. Mindez nem jelenti azonban azt, hogy a múltról szóló interpretációk eleve hamisak vagy értéktelenek, ugyanakkor mindig figyelembe kell vennünk azt, hogy csak közvetetten és a saját koruk és körülményeik által is befolyásolt módon adnak képet a múltban történtekről (Barton és Levstik, 2004.)

Az interpretáció céljától, célcsoportjától és a szerző megközelítésmódjától függően a témák, források, a nézőpontok és szempontok közötti válogatás különböző kritériumok szerint történhet. Más-más részletekkel foglalkozik egy okokra magyarázatot kereső elemzés és egy eseménytörténeti áttekintés. A szerzők nézőpontja és vizsgálati 
szempontjai jelentősen befolyásolják, hogy ki, mikor, miknek tulajdonít jelentőséget, illetve kiket és miket tart fontosnak az adott interpretáció elkészítése szempontjából (Cercadillo, 2000). Az események, szereplők és körülmények kiválogatása során a történész eldönti, hogy a történetek magyarázata és értelmezése szempontjából mi a fontos. De ez a válogatás sokféle eredményre vezethet, többféle egyformán érvényes megoldása lehet.

Nincs önmagában álló, az interpretációtól függetlenül megragadható történelmi tény sem (Körber, 2011). A történelem nem a tények összegyüjtésén alapuló kumulatív tudomány, hanem inkább egy „konstruktív, retorikai tevékenység, amely valamilyen valószínüség megállapításához vezet [...] egy olyan következtetés, amely a történelmi bizonyítékokon és a történész szelektív figyelmét irányító értelmezési kereten alapul" (Greene, 1994. 92.).

A múlt feltárása és az eredmények felhasználása például a jelen megértéséhez összetett és bonyolult. A „,örténelem több annál, mint amit abból mai világunk értelmezésekor hasznosítani tudunk, és jelenünk is több annál, mint amit abból történeti elemzéssel megérthetünk. Másrészt a történelmi magyarázat soha nem abszolút érvényü." (Knausz, 2015. 22.) Annak, hogy a múltban történteknek miként próbálunk értelmet adni történelemként, számos módja és formája van. Az interpretációk tartalmát mindig többféle tényező együttesen határozza meg: a kontextus, amelyekben megszületettek; az a mód, ahogy a történelem fogalmát értelmezik; az általuk alkalmazott értelmezési keret és azok a múfajok és kifejezési formák, amelyekben megfogalmazásra kerültek. Fontos szerepet játszik a múlt különböző megközelítésmódja is. Ez lehet a jelen azonosítása a múlttal (vagy a folytonosság megerősítése köztük), vagy a jelen megkülönböztetése a múlttól (vagy a megszakítottság megerősítése), vagyis a múlt értékrendjének megerősítése vagy megcáfolása (Chapman, 2011).

A céljaik szempontjából a történelmi interpretációk nagy többsége négy jellemző típusba sorolható:

- identifikáló: kapcsolatokat keresünk önmagunk és a múltban élt emberek között

- moralizáló: megemlékezünk a tragikus eseményeket átélt emberek áldozatvállalásáról és szenvedéseiről, illetve erkölcsi ítéleteket alkotunk történelmi eseményekről, cselekedetekről és személyekről

- elemző: minél jobban meg akarjuk érteni a jelenkori viszonyok történelmi előzményeit; azonosítjuk az események különböző jellegzetességeit, vizsgáljuk az okokat és következményeket; a bizonyítékokon alapuló következtetések levonása céljából kérdéseket fogalmazunk meg; elsődleges forrásokat keresünk és válogatunk, az ellentmondó forrásokat összehasonlítjuk és értékeljük

- ismeretterjesztő: történelmi információk minél érthetőbb és minél érdekesebb megjelenítésére törekszünk oktatási és szórakoztatási célokból (Barton és Levstik, 2010).

Az, hogy egy történész milyen típusú történelmi munkát akar írni, jelentős mértékben meghatározza, hogy a munkája miröl fog információkat tartalmazni és miröl nem, és azt is, hogy miként strukturálja ezeket az információkat és miként építi fel belölük a múltban történtek elbeszélését vagy bemutatását (Chapman, 2016).

A múltról szóló elbeszélésekben mindig sokféle szándék és értelmezés ágyazódik be. Döntő fontosságú a többszempontú megközelítés kezelése annak érdekében, hogy a különböző értelmezéseket „történelemnek” tekintsük, mivel a narratíva mindig retrospektív, valamilyen nézőpontú, szelektív és részleges konstrukció. A multiperspektivikus kutatási és oktatási mód magában rejti „azt az ígéretes, bár sok türelmet igénylő lehetőséget, hogy a témához hozzászóló mindegyik fél a valóság és az igazság elérésére való törekvés közben együtt, közösen egy mélyebb/elmélyültebb tudás (igazság) birtokába jut vagy juthat" (Vajda, 2020. 69.). 
A múlt valóságát azonban sohasem lehet teljesen összerakni a forrásokból, és a feltárt részletek alapján megfogalmazott következtetéseket sem lehet soha végső és vitathatatlan igazságokként kezelni. A múltból ránk maradt források önmagukban nem válaszolják meg a kérdéseinket, de lehetőséget adnak arra, hogy bizonyítékokként használva őket hihetőnek tekinthető, ésszerü következtetésekre tudjunk jutni arról, hogy mi és hogyan történhetett (Lee, 2005). Ahogy Norman Davies angol történész találóan megfogalmazta: „A múlt rekonstruálása a versfordításokhoz hasonlítható. Meg lehet csinálni, de egyetlen fordítás soha nem tudja pontosan megragadni az eredeti vers minden árnyalatát. Akár őskori receptekkel, gyarmati településekkel vagy középkori zenével foglalkozunk, nagy képzelőerőre és visszafogottságra egyszerre van szükség ahhoz, hogy elkerüljük a fantáziátlan hitelesség és a felszínes empátia kettős veszélyét.” (Davies, 1997. 119.)

\section{A történelmi interpretációk értékelése}

Feltevések és értelmezési keretek alakítják a történelmek írását, valamint az a tágabb környezet, amelyből származnak. Az értelmezésbeli különbségekről való gondolkodás során fontos annak megértése, hogy az, amit a történészek mondanak, hogyan függ össze azzal a korral és helyzettel, amelyben dolgoznak. A történelemről szóló szövegek esetében is nagyon fontos a szerzői perspektíva megértése, és mivel a szerzők szociokulturális háttere eltérő, a szerzők ugyanazt a történelmi eseményt markánsan eltérő módon írhatják le. Ezért egy interpretáció értékelése előtt minél pontosabban meg kell ismerni és érteni azt a kontextust, amiben és amihez az interpretáció készült. (Ki? Miért? Kiknek? Milyen céllal készítette?). Ezen információk fontosak, de ezek alapján még nem dönthető el, hogy az interpretáció mennyire elfogadható vagy elfogadhatatlan. A múltról készült történelmi interpretációk nagyon különböző célokból készülhetnek, ezért a történeti müveket és ábrázolásokat más-más szempontok szerint kell értékelni. Egy történelmi filmet értékesnek tarthatunk úgy, mint egy filmet, de ez nem keverendő össze a filmben ábrázoltak történelmi pontosságának és hitelességének megítélésével (Rose és Corley, 2003).

Nem helyes, vagy éppenséggel eltorzított interpretációk mindenhol megjelenhetnek, függetlenül az adott történelmi interpretáció céljától és műfajától. Egy politikai beszéd is mentes lehet ezektől, és egy tudományos cikkben is előfordulhatnak. Altalában persze gyanakvóbbak vagyunk egy történelmi eseményt felidéző politikai beszéd esetében, de fontos, hogy az értékítéletünk ilyenkor is a beszéd tartalmának vizsgálatán alapuljon.

Gyakori, hogy a történelmi eseményekkel kapcsolatos, tényszerünek tünő megállapításokról is éles viták alakulnak még a kortárs történészek között is. Ez nem feltétlenül jelenti azt, hogy az egyik szerző hazudik, és a másik igazat mond, vagy azt, hogy minden történelem kitaláció, bár sok közülük fikciókat tartalmaz (VanSledright, 2014).

Abból azonban, hogy általában elfogadhatónak, sőt természetesnek tartjuk, hogy a történészek különböző értelmezési módokat választhatnak, nem következik az, hogy minden ilyen döntés egyformán védhető. A pozitivista realizmus és a relativista - néha szkeptikus - posztmodernizmus közötti történelemfilozófiai vita közepette a történészi gyakorlat általában a korlátozott „objektivista” álláspontot képviseli, amely minőségi kritériumokat alkalmaz a különféleképpen megragadható múlt interpretációinak az összehasonlításához. Ilyen kritérium a pontosság, az átfogóság vagy a konzisztencia (Cercadillo, 2000).

Vannak olyan történelmi interpretációk, amelyek különböző célokból szándékos hazugságokat és kitalációkat is tartalmaznak a múltban történt eseményekröl, cselekedetekről, vagy éppen tagadják bizonyos események megtörténtét. Sokkal jellemzőbb azonban, amikor a történelmi interpretációk torzításaihoz a szerző elfogultságából, 
felkészületlenségéből vagy a meggyőzés szándékából fakadó hibák vezetnek (Fischer, 1970). Olyanok, mint

- egyes feltételezések tényként vagy megfellebbezhetetlen igazságként való beállítása

- egyes feltételezések kategorikus kizárása

- egyes feltételezések igazságként való beállítása bizonyítékok nélkül

- csak egyetlen nézöpont vagy szempont figyelembe vétele

- releváns nézőpontok és szempontok ignorálása vagy megkérdőjelezése

- tények tendenciózus válogatása

- tények tendenciózus összefüggésekbe állítása

- hamis cél- és szándéktulajdonítás

- az interpretáció nézőpontjának és szándékának elrejtése, homályban hagyása

- a felhasznált források, bizonyítékok ellenőrzésének megnehezítése vagy megakadályozása

A történész nézőpontokat és szempontokat választ, és ezáltal az egyes dolgok jelentősége is megváltozik (Ankersmit, 1983). A történetírás egyik legfigyelemreméltóbb vonása az események bemutatásának, magyarázatának és interpretációjának a sokfélesége, valamint azok időbeli változásai (Cercadillo, 2000). A történészek többféle feladatra vállalkozhatnak és sokféle kérdést tehetnek fel. Az általuk végzett történeti kutatások például különbözhetnek területi kiterjedésükben, időintervallumukban és problémamegközelítésük szélességében egyaránt. Az egyik szerző a nagyszabású eseményeket és folyamatokat igyekszik bemutatni, a másik kisebb témákra koncentrál. A történelmi interpretációk összehasonlításakor először azonosítani kell az eltéréseket, majd meg kell érteni, hogy szerzők milyen értelemben és miért értelmezték különböző módon a történteket. Lehet, hogy nem ugyanazt tartják egy témával kapcsolatban érdekesnek és fontosnak, és nem ugyanazokra a kérdésekre keresnek választ. A különbség fakadhat abból is, hogy különböző forrásanyagokat dolgoznak fel és más-más módszereket alkalmaznak a forrásaik értelmezésére. Az is vitákhoz vezethet, ha nem ugyanazokat a fogalmakat használják az általuk vizsgált események, jelenségek és információk értelmezéséhez és bemutatáshoz.

Különbségek abból is adódnak, hogy a történészek az „értelmezési ciklus” eltérö szakaszaiba kapcsolódnak be, és eltérő célú és müfajú publikációkat készítenek. Amit ugyanis a történész csinál, az része egy folyamatosan zajló történelmi feltáró munkának, ez az aktuális tudományos környezet pedig meghatározó módon hatással van az ő munkájára is (1. ábra). Maga is különféle módon kapcsolódhat be ebbe a folyamatba. Lehet, hogy egy újonnan azonosított archívum, forrásegyüttes feltárását végzi el. Lehet, hogy egy már zajló történelmi vita szempontjainak kiszélesítésére vagy az ahhoz használt fogalmak körének tekintetében tesz új javaslatokat. Lehet azonban az is, hogy a javaslatai egy historiográfiai konszenzus megkérdőjelezésére és felülvizsgálatára irányulnak (Chapman, 2016). 


\section{A kutatás, vita és interpretáció ciklusa}

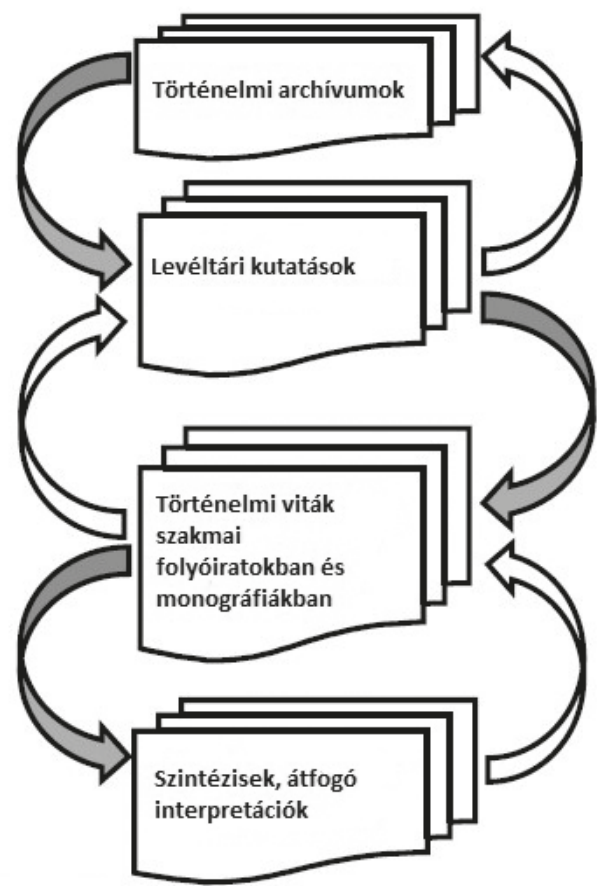

1. ábra. A kutatás, vita és interpretáció ciklusa (Chapman, 2016. 24.)

\section{A történelmi interpretáció fogalmának jelentősége a történelemtanulásban}

A történelmi megértés bonyolultabb, mint a múlt tartalmának, vagyis statikus tényeknek a megértése. Ahogy Peter Seixas mondja, a diákok különféle ellentmondásos történelmi interpretációknak vannak kitéve az iskolán belül és kívül, és ,eszközökre van szükségük ezen interpretációk relatív erősségeinek és gyengeségeinek megítéléséhez" (Seixas, 2000. 25.). Összetett, ugyanakkor nagyon fontos feladat képessé tenni a diákokat a történelmi interpretációk helyes értelmezésére és a különböző célú és minőségü interpretációk kritikus értékelésére.

A történelemtanulás eredményeként a tanulóknak elsősorban azt kellene megérteni, hogy a történelmi interpretációk a múltról utólag készített ábrázolások és konstrukciók, amelyek éppen ezért egymástól sokféleképpen eltérők és változatosak, és az idők során folyamatosan változnak. Jellemzően bizonyítékokon és érveken alapuló elbeszélések, de sohasem mentesek a szerzőik szubjektivitásának hatásaitól. Fel kellene tudniuk ismerni, hogy a különböző történelmi interpretációk milyen kérdésekre adnak választ, és milyenekre nem, és mindez minként függhet össze szerzőik helyzetével és szándékaival, illetve az interpretációk műfajával és elkészítésük céljával. Értelmes magyarázatokat kellene tudniuk adni arra is, hogy miért alakulnak ki viták a történészek között, és miért hasznosak ezek a történettudomány szempontjából. Ismerniük és alkalmazniuk kellene azokat a kritériumokat és módszereket, amelyek segítségével képesek lehetnek összehasonlítani az egymástól eltérő történelmi interpretációkat akár a tényszerü megalapozottság, akár a 
problémaérzékenység szempontjából úgy, hogy minderről értelmesen ki is tudják fejteni a véleményüket (Chapman, 2016).

Az a történelemoktatás, amely „csak arra összpontosít, hogy a diákoknak átadjon egy egyetlennek és változtathatatlannak feltüntetett interpretációt és elrejti a tanulók elől a történelmi elbeszélések és ismeretek (beleértve a történelemtankönyvek) konstruált természetét, valamint azt is, hogy ezek a történelmi interpretációk sohasem csak a múltról szólnak, hanem a jelenkori társadalmak politikai céljait is szolgálják", nem tölti be megfelelően a feladatát (Körber, 2012. 14.). Ezen ismeretek nélkül ugyanis a diákok nem lesznek fogékonyak és képesek a történelmi interpretációk kritikus kezelésére.

Peter Seixas és Carla Peck (2004) is azt emelte ki, hogy a tanulók képesek legyenek kritikusan közelíteni a múltról szóló feldolgozásokhoz és beszámolókhoz, legyenek azok akár történelmi filmek, regények, akár tankönyvek, ismeretterjesztő müsorok, tudományos cikkek, vagy akár otthon hallott visszaemlékezések. A történelmi gondolkodás fejlesztése az ő felfogásuk szerint azon képességek kialakítását jelenti, amelyek ehhez a kritikusan reflektáló értelmezéshez szükségesek. Ehhez a legjobb mintát és a modellt a történészek által kialakított szabályok és módszerek jelentik.

Az Egyesült Államokban a U.S. History Test készítői praktikus megfontolásokat követve a következő két részre bontották a történelmi tudást:

- történelmi ismeret és perspektíva;

- történelmi elemzés és interpretáció.

A történelmi ismeret és perspektíva a történelmi tudás tartalmi oldalát jelentette. Ennek tekintették a történelmi témákról, korszakokról és régiókról szerzett ismereteket, és ide sorolták a különböző személyek, események, fogalmak, témák, mozgalmak, kontextusok és történelmi források megismerését és megértését is. Ugyanakkor a tartalmi tudás alatt nemcsak a történelmi ismereteket értették, hanem a történelmi ismeretek rendszerezéséhez és általánosításához szükséges tudást is, pl. az események sorrendbe állítását, a többféle lehetséges nézőpont felismerését, a múlt eseményeinek a vizsgálatát és megértését az azokat átélő különböző csoportok szemszögéből, és végül egy általános kép kialakítását az USA történelmének legfontosabb sajátosságairól. A történelmi elemzés és interpretáció kategóriájába a történelmi tudás jártasságot igénylő elemeit sorolták, úgymint a problémák bemutatása, a történelmi modellek azonosítása, az ok-okozati összefüggések megállapítása, a jelentőségre vonatkozó értékelés elvégzése, valamint a történelmi ismeretek alkalmazása, a bizonyítékok mérlegelése megalapozott következtetések levonásához és érvekkel alátámasztott általánosítások megfogalmazása, lényeglátó beszámolók készítése a múlt eseményeiről (Seixas és Ercikan, 2015).

A University of Amsterdam kutatói, Jannet van Drie és Carla van Boxtel a korábbi kutatások eredményeit összesítve alkották meg a maguk kognitív modelljét a történelmi gondolkodásról. A historical reasoning fogalmát az oktatás kontextusában értelmezték, és a következőképpen határozták meg: ,olyan tevékenység, melynek során valaki a múltról szóló információkat úgy és azért rendezi össze, hogy leírja, összehasonlítsa és/vagy megmagyarázza a történelmi jelenségeket" (van Drie és van Boxtel, 2008. 89.). Ezen összetett tevékenység hat alkotóelemét különítették el: történelmi kérdések megfogalmazása; források használata; kontextusba helyezés; érvek megfogalmazása; szubsztantív fogalmak használata; metafogalmak használata. A kutatók fontosnak tartották kiemelni, hogy e modell a történelemtanulást aktív tevékenységként értelmezi. A tanulóknak az új ismeretek megszerzése során az események megértéséhez és interpretálásához folyamatosan mozgósítaniuk kell a korábbi tudásuk többféle rétegét is.

A múltat a különféle egymást erősítő vagy egymással vitatkozó interpretációk láncolatán keresztül ismerhetjük csak meg. A múlt megértéséhez a történelmi gondolkodás stratégiáinak elsajátítására és használatára van szükség. VanSledright a mélyebb történelmi 
megértést lehetővé tevő stratégiai tudásbeli készségek közé a következőket sorolta: források értő és kritikus olvasása; a különböző forrásokon alapuló információk és következtetések összehasonlítása; a tényeken alapuló és kontextusba ágyazott interpretáció; az interpretációkat készítő szerzők perspektívájának és pozíciójának mérlegelése; az esemény, személy vagy változás történelmi jelentőségének megítélése (VanSledright, 2010).

\section{A tanulók gondolkodásának jellemzői}

Még az idősebb diákok számára is gondot jelent a komplex történelmi interpretációk és narratívák helyes értelmezése. Ezt akadályozhatja a mélyebb és szélesebb történelmi ismeretek hiánya is. Ugyanakkor a diákok eleve hajlamosak a leegyszerüsítésekre, vagy hogy az elbeszélés egyenesvonalúságának fenntartása érdekében a valóságban meg nem történt részleteket találjanak ki. Jellemző még az események egyoldalú megközelítése, a történteknek szinte kizárólag a domináns szereplők és csoportok szemszögéből történő bemutatása, valamint egyes esetekből és jelenségekböl általános következtetések levonása (Levstik, 2010).

A kutatások azt mutatják, hogy a diákoknak a saját mindennapi ismeretek alapján gyakran megvannak a maguk hallgatólagos előfeltételezései a történelmi ismeretek elöállításáról. E naiv feltételezések pedig valószínüleg akadályozzák a történelmi interpretációk helyes értelmezését (Lee, 1997, 1998, 2001; Lee és Shemilt, 2004). Sok diák számára például az „,igazmondás” a múltról egyenlő azzal, hogy létezik az eseményeknek egy egyedül lehetséges változata (Jones, 2011). Azok a diákok, akik a múltat valami fixen megismerhetö dolognak gondolják, hajlamosak az egymástól eltérő interpretációkat a szerzők szubjektivitásával, elfogultságával megmagyarázni, a mindennapi episztemológiát alkalmazva a történelmi megismerés folyamatát elsősorban a közvetlen tapasztalatokon és a szemtanúk beszámolóin alapuló tevékenységként értelmezni (Chapman, 2012). Sok tanuló úgy képzeli, hogy a történeti források olyanok, mint a szemtanúk vallomásai, amelyek pontosan beszámolnak arról, hogy „mi történt”. Tehát a történész feladata először megbízható forrásokat találni, aztán pedig ezekből összerakni a múlt valós „képét” úgy, ahogyan egy kirakót vagy egy összetört mozaikot szoktunk
A 7 és 14 év közötti diákokkal kapcsolatban a kutatók azt találták, hogy a legtöbb diák, a legfiatalabbak kivételével, felisdelkezésre állásának és értelmezésének különbségei eltéró beszámolókhoz vezethetnek, de egyesek számára ez azt jelennem tudnak valamit biztosan, egyszerúen pótolják azt, ami hiányzik. Ezek a diákok úgy beszéltek az interpretációkról, mintha szinonimái lennének mivel mindenkinek joga van a saját véleményéhez, úgy gondolták, hogy mindegyik egyformán érvényes. Ezek a diákok úgy gondolják, minden elfogadható, mert a versengố vélemények között úgysem lehet dönteni (Ashby és Lee, 1987). A gyerekek arra a következtetésre jutnak, hogy a történelmi források mindig elfogultak és hiányosak, így nincs mód eldönteni, hogy mi történt az egyik ötlet ugyanolyan jó, mint a másik (Barton és Levstik, 2004). merte, hogy a bizonyitékok rentette, hogy amikor a történészek a személyes véleményeknek, és 
összeállítani (Chapman, 2016). A diákok úgy vélik, hogy a történészeknek ahhoz, hogy feltárják a történtek ,igazságát”, olyan beszámolók készítésére kell törekedniük, amelyek nem tartalmaznak elfogultságokat, és nem homályosítják el a szerző tisztánlátását személyes nézőpontok. Nem érzékelik, hogy a történészek elméletekről és módszerekről alkotott nézetei elkerülhetetlenül befolyásolják az általuk választott bizonyítékokat, és azt is, hogy azokat hogyan fogják kezelni, és milyen következtetéseket fognak levonni belölük (David és Zaiba, 2019).

A 7 és 14 év közötti diákokkal kapcsolatban a kutatók azt találták, hogy a legtöbb diák, a legfiatalabbak kivételével, felismerte, hogy a bizonyítékok rendelkezésre állásának és értelmezésének különbségei eltérö beszámolókhoz vezethetnek, de egyesek számára ez azt jelentette, hogy amikor a történészek nem tudnak valamit biztosan, egyszerüen pótolják azt, ami hiányzik. Ezek a diákok úgy beszéltek az interpretációkról, mintha szinonimái lennének a személyes véleményeknek, és mivel mindenkinek joga van a saját véleményéhez, úgy gondolták, hogy mindegyik egyformán érvényes. Ezek a diákok úgy gondolják, minden elfogadható, mert a versengő vélemények között úgysem lehet dönteni (Ashby és Lee, 1987). A gyerekek arra a következtetésre jutnak, hogy a történelmi források mindig elfogultak és hiányosak, így nincs mód eldönteni, hogy mi történt - az egyik ötlet ugyanolyan jó, mint a másik (Barton és Levstik, 2004).

A kutatások alapján tehát megfogalmazható néhány jellemző és makacs tanulói tévhit a múlt interpretálásáról:

- a múltról készített interpretációk közvetlen ablakot nyitnak a múltra, hiszen képesek a valóságnak mindenben megfelelö, teljes képet adni nekünk a régen történtekről

- minden múltbeli eseményről elkészíthető egy lehető legjobb történelmi interpretáció, egy olyan, a valóságnak megfelelő, végső igazságokat és következtetéseket megfogalmazó változat, amely egyszer és mindenkorra tisztázhatja a felmerült és vitatott kérdéseket

- az egymástól eltérö történelmi interpretációkat eleve gyanakodva érdemes kezelni, mivel az eltérések csak szubjektív okokkal magyarázhatók (pl. valamelyik fél téved, vagy szándékosan el akarja torzítani a valóságot)

A történelmi interpretációkkal összefüggő tanulói gondolkodás fejlődésének jellemző szintjeit Arthur Chapman a következőképpen írta le:

1. Az interpretációk és múltban történtek pontosan megfelelnek egymásnak.

2. Az interpretációk nem lehetnek a múltban történtek pontos tükrei, mert mi nem tudunk a régen történtek szemtanúi lenni.

3. Az interpretációk a múltban történtek pontos tükrei, feltéve, hogy nincsenek bennük hibák és hézagok.

4. Az interpretációkat eltorzíthatják hátsó szándékból.

5. Az interpretációk formálásában a személyes szempontok is szerepet játszanak.

6. Az interpretációk akkor megfelelőek, ha válaszolnak a feltett kérdésekre, és megfelelnek a történelmi állításokkal szemben támasztott kritériumoknak.

Chapman szerint a modell 4. szintje előtt a diákok hajlamosak úgy értelmezni a történeti beszámolókat, mint amik egy fix múlt teljesen helyes vagy hibás másolatai. A 4. és az 5. szinten a diákok általában úgy értelmezik a történeti beszámolókat, mint szándékosan vagy csak a szubjektivitásból fakadóan elferdített interpretációkat, és csak a 6 . szinten kezdik úgy értékelni a történelmi interpretációkat, ami összhangban áll a történettudományi szemlélettel.

Fontos figyelembe venni, hogy a diákok interpretációkkal kapcsolatos gondolkodása összefüggésben áll más értelmező kulcsfogalmak megértésével. A kutatók gyakorta az tapasztalták, hogy azok a diákok, akik behatároltan gondolkodtak az interpretációkról, 
nagyon leegyszerüsítve gondolkodtak a bizonyítékokról is, azt feltételezve például, hogy a történészek elsősorban szemtanúk beszámolóira támaszkodnak, és megbízható beszámolókból állítják össze az igazságot. Az interpretációkkal kapcsolatos gondolkodás fejlesztése és a bizonyítékok megértésének fejlesztése valószínűleg párhuzamos és szorosan összekapcsolódó feladatok (Chapman, 2016).

\section{A tanulók gondolkodásának fejlesztése}

A történelemtanítás eredményeként a tanulókban ki kellene alakulni egy értően kritikus szemléletnek a múlt ábrázolásaival kapcsolatban is, hogy a történelmi eseményekről szóló elbeszéléseket, leírásokat, magyarázatokat stb. ne kezeljék úgy, mintha a múltban történtek pontos másolatai volnának. Természetes dolognak tekintsék, hogy a múlt eseményeiről folyamatosan különféle, egymással nem mindenben megegyező interpretációkkal találkoznak. Ehhez meg kell érteniük és meg is kell magyarázniuk, hogy a múltat hogyan és miért interpretálják különféleképpen.

A 2010-es évek angol tanterveiben egész konkrét tanulási követelmények jelentek meg a történelmi interpretáció kezelésével kapcsolatban:

- Az 5 és 14 év közötti tanulók felismerik, hogyan és miért születnek a múltban történtek egymástól eltérő vagy éppen ellentétes értelmezései, interpretációi.

- A 14-16 éves diákok a megfelelő médiumok felhasználásával megértik, elemzik és értékelik, hogy a múltat hogyan értelmezték és ábrázolták különböző módon.

- A 16-19 éves korosztály tanulói felfogják, elemzik és értékelik, hogyan értelmezték és ábrázolták a múltat különböző módon. Olyan példákon keresztül, mint történészek vitái, vagy a múltban történtek megjelenítése festményeken, filmekben, rekonstrukciókban, múzeumi kiállításokon és az interneten. (Chapman, 2014)

Fel kell ugyanakkor készíteni a tanulókat arra is, hogy készek és képesek legyenek különbséget tenni a történelmi interpretációk között azok tényszerü megalapozottsága, valószínüsíthetősége, valóságábrázolásuk mélysége, érvelésük minősége és a további vitákra való nyitottságuk szempontjából. Segítenünk kell a diákoknak abban is, hogy a történettudományi munkákat is olyan konstrukcióknak lássák, amelyeket a történészek készítenek, nem pedig készen találják azokat, és éppen ezért sokkal inkább hasonlítanak kérdésekre választ kereső teóriákra, mint kész és teljes képekre. Példákon keresztül betekintést kell adni a történelmi kutatómunka folyamatába, hogy lássák: a történészeknek is, mielőtt bármit is elkezdenének kutatni és értelmezni, dönteniük kell arról, hogy mely kérdésekre fognak választ keresni, és melyekre nem. Ugyanígy arról is, hogy hogyan határozzák meg a múltban történtek bemutatásához használt fogalmakat, és milyen forrásokat fognak mindehhez felhasználni. A tanulóknak meg kell érteniük, hogy az interpretációkat mindig valamilyen okból és mindig egy adott társadalmi kontextusban hozzák létre. Hiszen ezek egy nemzedékeken átívelő közösségi párbeszéd részei, amely a múltban történtek minél sokrétübb feltárásáról és értelmezéséről szól, és a sokféle interpretáció e folyamatos újraértelmezésnek köszönhető. Mint ahogy ez a tudományos közösségben is megfigyelhető: az egyik történész válaszol egy másik történész által megfogalmazott értelmezésre, amelyet valamilyen oknál fogva hiányosnak és kiegyensúlyozatlannak tart, vagy amelynek bizonyítékai nem elég meggyőzők. Az is lehet azonban, hogy újonnan feltárt forrásokra támaszkodva, vagy új szempontokat felismerve eredeti következtetésekkel áll elő, amiről aztán újabb viták keretében más történészek is megfogalmazzák a véleményüket. Ha a diákok képessé válnak így látni a történettudomány munkáját is, nem a történelmi témákról folyó vitákat, hanem a történelmi múlt igazságairól szóló kinyilatkoztatásokat fogják gyanúsnak és természetellenesnek tartani. 
Ehhez legfőképpen az szükséges, hogy a diákoknak az iskolai oktatás során is legyen lehetőségük egymással ellentétes történelmi interpretációkkal találkozni, azok összehasonlítását és értékelését gyakorolni. A tanáraik irányításával így egyre inkább képessé váljanak annak felismerésére, hogy a történeti interpretációk miben és miért különböznek egymástól. A történeti interpretációk értékelése azonban általában nehézséget okoz még a jobb képességü diákoknak is. Gyakran megfigyelhető a „konfliktuskerülés", amikor a diákok kerülik az interpretációk közötti megkülönböztetést, és kritika nélkül elfogadják az azokban szereplő történelmi érveléseket. Az is jellemző probléma, amikor a diákok felszínes ítéleteket hoznak például olyan naiv kritériumok alapján, mint hogy mikor készült az interpretáció (minél később, annál jobb), mennyi konkrét adatot tartalmaz (minél többet, annál hitelesebb), hogyan viszonyul a bemutatott eseményekhez (minél semlegesebben, annál megbízhatóbb). A felszínes értékelés egy másik típusa, amikor a diákok ,mindent vagy semmit” típusú véleményt alakítanak ki az egymással összehasonlított interpretációkról: a valamiért meggyőzőbbnek tartott interpretáció minden állítását és érvét elfogadják, míg a másikét teljesen elutasítják, ahelyett, hogy többféle szempontból is mérlegelnék az egymással vitatkozó interpretációk erősségeit és gyengeségeit.

Fontos lenne tehát, hogy az értékeléskor képesek legyenek reflektálni az interpretációk érvelésére és az ehhez bemutatott bizonyítékokra is. Ne csak a tartalomra koncentráljanak, hanem azonosítsák az interpretációk tartalmat meghatározó szerzői szándékokat és módszereket is (Lord, 2014).

Például ilyen kérdések alapján:

- Van-e közös kiinduló alap, közös nevező, amiben a történészek egyetértettek?

- Mik a vitatott következtetések, értékelések és érvek? A vita néhány alapvető tényről szól, vagy abból fakad, hogy az elfogadott tényekből eltérő következtetéseket vontak le?

- A történészek ugyanazokat a kérdéseket tették fel, vagy egymástól eltérő kérdésekre akartak válaszolni az adott eseménnyel vagy korszakkal kapcsolatban? (Pl. Elsősorban leírni, megmagyarázni vagy értékelni akarták-e a történteket?)

- A történészek ugyanazt a forrásanyagot használták?

- A felhasználható források relevanciáját, hitelességét és megbízhatóságát ugyanúgy ítélték meg?
A tanulóknak meg kell érteniük, hogy az interpretációkat mindig valamilyen okból és mindig egy adott társadalmi kontextusban hozzák létre. Hiszen ezek egy nemzedékeken átiveló közösségi párbeszéd részei, amely a múltban történtek minél sokrétúbb feltárásáról és értelmezéséról szól, és a sokféle interpretáció e folyamatos újraértelmezésnek köszönhetó. Mint ahogy ez a tudományos közösségben is megfigyelhetó: az egyik történész válaszol egy másik történész által megfogalmazott értelmezésre, amelyet valamilyen oknál fogva hiányosnak és kiegyensúlyozatlannak tart, vagy amelynek bizonyitékai nem elég meggyózók. Az is lehet azonban, hogy

újonnan feltárt forrásokra támaszkodva, vagy új szempontokat felismerve eredeti következtetésekkel áll eló, amiról aztán újabb viták keretében más történészek is megfogalmazzák a véleményüket. 
- Van-e eltérés a történelmi kontextus értelmezésében, például a korabeli emberek gondolkodásmódja és viselkedése, a történelmi szituáció összetevőinek rekonstruálása, az eseményekben meghatározó szerepet játszó személyek, döntések, konfliktusok tekintetében?

- Van-e eltérés abban, ahogy az interpretációban fontos szerepet játszó fogalmakat definiálják és használják (pl. forradalom, diktatúra, konjunktúra)?

Egy megfelelö kérdéssor segítséget adhat a diákoknak a történészek érvelésének a megértéséhez és összehasonlításához is.

- Miről akar a történész meggyőzni minket?

- Milyen érveket és bizonyítékokat mutat be állításainak és következtetéseinek alátámasztására?

- Hogyan illeszkednek egymáshoz a fő mondanivalóját bemutató állítások és bizonyítékok?

A diákoknak meg kell érteniük a történészek érveit: mire következtetnek, és mivel támasztják alá a következtetéseiket. Ennek gyakoroltatása azzal kezdődik, hogy egyáltalán megtalálják-e ezeket a történészek által írt cikkekben vagy a tévés dokumentumfilmekben. Ebből az is következik, hogy az értékelés nem a tények egyszerü ellenőrzését jelenti, hanem ennek során részletesen foglalkozni kell a történészek következtetéseivel és érveivel. A múltról készült interpretációk fontos pozitívuma lehet a szerző által feltett történelmi kérdések relevanciája, a forrásanyag feltárásának és értelmezésének újszerüsége és a következtetések jelentősége és eredetisége (Chapman, 2016; Hibbert és Zaiba, 2019).

A tanulók által elvégzett értékelések során a tanárnak rendszeresen emlékeztetni kell őket arra, hogy a történelmi interpretációk értékelése mindig az interpretáció céljaitól, illetve a szerzője által feltett kérdésektől függ. Mennyire felelt meg ezeknek a céloknak és mennyire adott meggyőző válaszokat a kérdésekre? A diákoknak különféle történelmi munkákkal kellene találkozniuk, különös tekintettel azokra, amelyek jól megjelenítik számukra is a történészek céljai és módszerei közötti különbségeket: pl. a történelmi fókusz fajtáit (társadalomtörténet, gazdaságtörténet stb.); a fókusz skáláját (egyének, falvak, birodalmak stb.). Különösen érdekes lehet a különbség abban, hogy milyen szerepet vállal fel a mü egy téma feltárásában: pl. egy korábban széles körben elfogadott tézist megkérdőjelezve merőben új interpretációt mutat be, vagy éppen ellenkezőleg, újabb kutatásokkal támaszt alá egy már régebben megfogalmazott történelmi értelmezését és értékelést. Az interpretációk fókuszainak megfigyelése vezethet el a történelemtanulás fókuszainak felismertetéséhez is: a fókusz ez esetben „egy adott tananyag tanításának értelme. Az, hogy meg tudjuk mondani, miért tanítjuk, azaz mi is tulajdonképpen a mondanivalónk" (Knausz, 2015. 78.). E különbségek nagyon jól érzékeltethetők lehetnek a történelmi témájú könyvek és cikkek címeinek, tartalomjegyzékének vagy kiadói ismertetőinek az összehasonlításával. Közben pedig azt is gyakoroltathatjuk a diákokkal, hogy mit lehet megtudni ezekből a kutatás témájáról, céljáról, kérdéseiről és módszereiről. A témák sokféle megragadása jól szemléltetheti a kutatómunkát jellemző innovációt és kreativitást is: pl. a történészek új forrásokat tárnak fel; új típusú adatokat használnak fel egy régóta tárgyalt problémára; új módon olvassák a már régóta ismert forrásokat. Arra is törekedni kell, hogy lássák, a különböző kutatási módszerek értéke is a kérdéstől és a feltárandó problémától függ: egyes módszerek bizonyos dolgok feltárását lehetővé teszik, míg más jellegü kérdések megválaszolására sokkal kevésbé alkalmasak.

Az interpretáció összehasonlításakor és értékelésekor szükséges foglalkozni azzal is, hogy mit gondolnak a diákok a történelmi elbeszélések szerzője által választott nézőpontról és az ennek nyomán az interpretációban explicit vagy implicit módon megjelenő 
elfogultságokról (F. Dárdai, 2006). Mikor, milyen mértékben és miért tartják ezt elfogadhatónak vagy elfogadhatatlannak? Eleve helytelenítik, ha a történészek egy bizonyos nézőpontot képviselnek beszámolójukban, vagy a történetírói „,nézőpont” megválasztását elkerülhetetlennek és szükségesnek tartják? (Cercadillo, 2000)

\section{Összegzés}

A múltról megszerezhető ismereteinket a régebben és újabban készült történelmi interpretációk láncolata hordozza. A múltban történtek megismerése e sokféle, hol egymást kiegészítő, hol pedig egymásnak ellentmondó interpretáció folyamatos mérlegelését jelenti. Ezeket hasonlítjuk össze a bennük található információk és megközelítésmódok jelentősége, újdonsága és tényszerü megalapozottsága szempontjából. Az interpretációk akkor helytállók, ha a világ dolgait úgy kapcsolják össze, hogy azokat megérthessük, és akkor tisztességesek, ha kiegyensúlyozott ábrázolást nyújtanak, kerülve a torzításokat.

A helyes történelemszemlélet alapja, hogy a diákokban is tudatosuljon: a múlt és a történelem nem ugyanaz. A valóságban lezajlott események nem reprodukálhatók, hanem csak interpretálhatók. A történelemtanításnak különböző példákon és feladatokon keresztül ennek minél mélyebb megértését is elő kell segítenie. Ahhoz kell intellektuális eszközöket adni, hogy képesek legyenek meglátni, milyen narratívákból áll, és milyen narratívák alakítják a történelmet. Ehhez pedig az szükséges, hogy történelem tanítása bizonyos fokú reflexivitással történjen, vagyis tegyük vizsgálat tárgyává a történelemórákon bemutatott állításokat és értékeléseket is.

\section{Irodalom}

Ankersmit, F. (1983). Narrative Logic. A semantic analysis of the historian's language. Martinus Nijhoff Publishers.

Ashby, R. \& Lee, P. (1987). Children's concepts of empathy and understanding in history. In Portal, C. (szerk.), The History Curriculum for Teachers. The Falmer Press.

Barton, K. C. \& Levstik, L. S. (2004). Teaching history for the common good. Routledge. DOI: $10.4324 / 9781410610508$

Barton, K. C. \& Levstik, L. S. (2010). Doing History: Investigating With Children in Elementary and Middle Schools. Taylor \& Francis. DOI: 10.4324/9781315818108

Cercadillo, L. (2000). Significance in History: Students' Ideas in England and Spain. Thesis presented for the $\mathrm{PhD}$ Degree in Education, Institute of Education University of London.

Chapman, A. (2011). Historical Interpretations. In Davies, I. (szerk.), Debates in History Teaching. 2nd Edition. Routledge.

Chapman, A. (2012). 'They have come to differing opinions because of their differing interpretations': Developing 16-19 year-old English Students' Understandings of Historical Interpretation through On-line. Inter-institutional Discussion. International Journal of Historical Learning, Teaching and Research, 11(1), 188-214. DOI: 10.18546/herj.11.1.13

Chapman, A. (2014). 'But it might not just be their political views': using Jörn Rüsens 'disciplinary matrix to develop understandings of historical Interpretation. Prepublication-Proof. libre.

Chapman, A. (2016). Developing Students' Understanding of Historical Interpretation. Edxecel / Pearson.

Davies, N. (1997). Europe a History. Pimlico Random House.

F. Dárdai Ágnes (2006). Történelemdidaktika és kontroverzív történelemtanítás. In: F. Dárdai Ágnes, Történelmi megismerés - történelmi gondolkodás. I. Eötvös Loránd Tudományegyetem Bölcsészettudományi Kar - Magyar Történelmi Társulat Tanári Tagozata. 30-43.

Fischer, D. H. (1970). Historians' Fallacies: Toward a Logic of Historical Thought. Harper \& Row.

Greene, S. (1994). The problems of learning to think like a historian: Writing history in the culture of the classroom. Educational Psychologist, 29(2), 89-96. DOI: $10.1207 / \mathrm{s} 15326985 \mathrm{ep} 2902 \_4$

Hibbert, A. \& Zaiba, P. (2019). Modelling the Discipline: How Can Yasmin Khan's Use of Evidence Enable Us to Teach a More Global World War II? Teaching History, 177, 8-15. 
Jones, C. (2011). An illusion that makes the past seem real: The potential of living history for developing the historical consciousness of young people. Thesis submitted for the degree of Doctor of Philosophy at the University of Leicester.

Koselleck, R. (2004). Futures Past: On the Semantics of Historical Time. Columbia University Press.

Körber, A. (2012). 'Uses' and 'ab-uses' of history. Possible consequences for history teaching at schools. URN: urn:nbn:de:0111-opus-66267 http:// nbn-resolving.de/urn:nbn:de:0111-opus-66267

Knausz Imre (2015). A múlt kútjának tükre. A történelemtanitás céljairól. Pedagógiai kultúra 2. Miskolci Egyetemi Kiadó.

Lee, P. J. (1997). „None of Us Was There”: Children's Ideas About Why Historical Accounts Differ. In Ahonen, S., Pauli, A. és mtsaik (szerk.), Historiedidaktik I Nordern 6, Nordisk Konferens om Historiedidaktik, Tampere 1996. Laererhojskle.

Lee, P. J. (1998). „A Lot of Guess Work Goes On”: Children's Understanding of Historical Accounts. Teaching History, 92, 29-35.

Lee, P. J. (2001). History in an Information Culture: Project Chata. International Journal of Historical Learning, Teaching and Research, 1(2). http://www. heirnet.org/IJHLTR/journal2/ journalstart.htm

Lee, P. J. (2007). From National Canon to Historical Literacy. In Grever, M. \& Stuurman, S. (szerk.), Beyond the canon. History for the Twenty-first Century. Basingstoke. 48-62. DOI: $10.1057 / 97802305992464$

Lee, P. J. (2004). Walking Backwards into Tomorrow' Historical Consciousness and Understanding History. History Education Research Journal 4(2). DOI: https://doi.org/10.18546/herj.04.1.03

Lee, P. J. (2005). Putting principles into practice: Understanding history. In Donovan, M. S. \& Bransford, J. D. (szerk.), How Students Learn: History in the Classroom. National Academies Press. 31-87.
Lee, P. J. \& Shemilt, D. (2004). "I Just Wish We Could Go Back in the Past and Find Out What Really Happaned." Teaching History, 117, 25-31.

Levstik, L. S. (2010). Learning history In Mayer, A. (szerk.), Handbook of Research on Learning and Instruction Edition. Routledge. 115-130. DOI: 10.4324/9780203839089.ch6

Lowenthal, D. (1985). The past is a foreign country. Cambridge University Press.

Rose, V. E. \& Corley, J. (2003). A Trademark Approach to the Past: Ken Burns, the Historical Profession and Assessing Popular Presentations of the Past. The Public Historian, 25(3), 49-59. DOI: 10.1525/tph.2003.25.3.49

Rüsen, J. (2005). History: Narration, Interpretation, Orientation. Berghahn Books. DOI: 10.2307/j. $\mathrm{ctt} 1 \times 76 \mathrm{fc} 2$

Samuel, R. (1994). Theatres of Memory: Past and Present in Contemporary Culture. Verso.

Seixas, P. (2000). "Schweigen! Die Kinder! Or, Does Postmodern History Have a Place in the Schools?' In Stearns, P., Seixas, P. \& Wineburg, S. (szerk.), Knowing, Teaching, and Learning History: National and International Perspectives. New York University Press.

Seixas P. \& Ercikan K. (2015). Introduction: The New Shape of History Assessments. In Seixas P. \& Ercikan K. (szerk.), New Directions in Assessing Historical Thinking. Routledge. 1-15.

Vajda Barnabás (2020). Multiperspektivitás és történelmi megbékélés. In Vajda Barnabás, Történelemdidaktika és történelemtankönyv-kutatás. Selye János Egyetem, Tanárképző Kar. 265-278.

Van Drie, J. \& Van Boxtel, C. (2008). Historical reasoning: Towards a framework for analyzing students' reasoning about the past. Educational Psychology Review, 20(2), 87-110. DOI: 10.1007/s10648-0079056-1

VanSledright, B. (2014). Assessing Historical Thinking and Understanding. Routledge. DOI: 10.4324/9780203464632

\footnotetext{
Absztrakt

A történelemtanítás és -tanulás eredményessége nagyrészt azon múlik, hogy a diákok képesek lesznek-e a múlt, a történelem és a történelmi interpretáció fogalmát helyesen értelmezni, helyes kép alakul-e ki bennük a múltban történtek és az azokról készült interpretációk viszonyáról. Ennek fontos feltétele, hogy a történelemtanárok maguk is megértsék e probléma összetettségét, és képesek legyenek reflektív módon is megközelíteni a történelemórákon bemutatott ismereteket, következtetéseket és értékeléseket.
} 